\title{
Board Composition and Innovation in University Spin-offs. Evidence from the Italian Context
}

\begin{abstract}
Antonio Prencipe
Abstract: Corporate governance issues are critical in university spin-offs because, since their substantially knowledge and technology-driven nature, investments are characterized by rapid growth and real investment opportunities, affecting innovative activity too. In this view, the paper investigate the role of the board of directors' composition on innovation performance of university spin-offs. Based on a panel sample of 478 Italian university spin-offs, the results show that board size has an inverted-U-shaped relationship with innovation, remarking that not too large boards are more efficient and work better, influencing in a positive way the innovation activity of the spin-off. Regarding the impact of the outside directors, the results seems to invalidate its positive and significant effect on innovation performance. Also the CEO-duality seems to have no influence on the innovative activity. These findings may represent potential indicators of the optimal configuration for board in university spin-offs in order to improve innovation.
\end{abstract}

Keywords: university spin-offs; innovation; board size; outside directors; CEO-duality; Italy.

Submitted: August 25th 2016 / Approved: September 12th 2016

\section{Introduction}

Over the past years, the attention given by the literature to the growth and innovative dynamics of entrepreneurship through university spin-offs, i.e. new technology-based firms (NTBFs) ge nerally small and medium enterprises (SMEs ) created with the support of the university and its members, has significantly increased (Niosi, 2006; Sternberg, 2014; Guerrero et al., 2016). These university start-ups constitute a potential active tool in stimulating the creation of value, innovation and the development of knowledge-based economies (Sternberg, 2014). Therefore, the determinants related to their genesis and growth have become key issues in the policy actions about the dissemination and the governance of innovation in specific environmental settings.

The literature focus mainly on the macro, meso and micro determination factors of growth and innovation of university start-ups (Djokovic \& Souitaris, 2008) but not among those have been deeply investigated the dynamics of the governance of the same. However, the relevance of corporate governance is recognized by the literature (Palumbo, 2010), also those involving companies with similar characteristics to the university spin-offs, such as new technology-based firms and high-tech SMEs (Colombo et al., 2014). The study of corporate governance assumes a particular prominence in the university spin-offs because, since their substantially knowledge and technology-driven nature, investments are often characterized by rapid growth and real investment opportunities. These elements may lead to generate a potentially high information asymmetry between management and owners (Gaver \& Gaver, 1995). Simultaneously, they may generate agency problems, since the aims and attitudes to risk valua- tion of the principal does not always match with those of the agent, especially in high-tech business (Hayton, 2005). In addition, there are considerable evidence that corporate governance affect innovation outcomes of the firms (Belloc, 2012). In this context, internal governance mechanisms, such as those related to the evolution and composition of the board of directors of the spin-off were considered potentially advocates and influencers to create value and innovation (Bjørnåli \& Gulbrandsen, 2010). On this view, the current study aim to investigate the role played by the board of directors, in its some different characteristics and composition, on innovation performance of university spin-offs by analysing a sample of 478 Italian university spin-offs extracted from Netval, Aida and Infocamere databases at 2015.The choice of Italy is not random; indeed, Italy is one of the major European countries reporting a rapid expansion of the university spin-off phenomenon (Iacobucci \& Micozzi, 2014).

The study aims to adds some conceptual and methodological insights to the literature. First, we add to the growing body of research on innovation by highlighting board of directors' composition as a potentially important determinant of innovation in university spin-offs. Second, the results arising from the study could be generalized beyond the Italian context, as the European university spin-offs share more of the same characteristics and peculiar issues (Visintin \& Pittino, 2014).

\section{Theoretical background and hypotheses development}

In the last years, the focus on corporate governance dynamics has grown significantly in management and innovation literature (Belloc, 2012). This also true especially with reference to the board composition and features of its directors. Nevertheless, governance studies 
have concentrated on large public firms instead in private small and medium sized firms (SMEs) and technology- and knowledge-based firms, as previously observed, the evidence on university start-ups are scarce. For this reasons, this paper focuses on the link between firm innovation and board composition, specifically refer to its size, the presence of outside directors and the CEO duality in university spin-offs.

\section{Board size and innovation in university spin-offs}

It was noted that larger boards are capable to provide the resources and know-how to perform additional and better monitoring, mainly in multifaceted contextual settings (Linck et al., 2008). Next, a greater amount of directors let the company to potentially access a superior pool of external resources, comprising financial and technological resources that are pivotal for innovation and spin-off in particular. Furthermore, according to the stakeholder theory, a greater board is able to hold other stakeholders in innovation, for instance strategic researchers, whose incentive might result in superior innovation activities (Adams et al., 2010).

With regard to the SMEs, evidences highlight that these firms have relatively a small number of directors on their board (Gabrielsson, 2007) and that increased board size may generate a positive impact on performance. The researchers in line with this vision claim that a greater board will bring together a better penetration of knowledge and, hence, lead to better strategic choices that finally affect performance.

Nevertheless, the benefits of add more directors can be compensated by the costs related to the inferior communication and decision-making linked with bigger board (Cheng, 2008). Indeed, greater boards are potentially less capable because the problems rising from the agency issues among the directors (Jensen, 1993). In this view, some studies highlight an inverse association between performance and the size of the board (Eisenberg et al., 1998). Hence, the influence of board size on firm performance and innovation is a trade-off between benefits and disadvantages (García-Olalla \& García-Ramos, 2010). Consequently, it could be argue a non-linear association between the size of the board and innovation in university spin-offs. Therefore, in line with the previous arguments, the following hypothesis was developed:

H1. There is an inverted-U-shaped relationship between the size of the board and innovation performance for university spin-offs.

\section{Outside directors and innovation in university spin-offs}

Outside directors play an important role in a firm. In the corporate governance studies, agency theory suggests that better monitoring mechanisms are required in order to safeguard shareholders from administration's self-interests and outside directors are potential protectors of the shareholders' interests through monitoring activity. Hence, a high fraction of outside directors on the board might generate a positive effect on performance, also in term of innovation, by monitoring facilities (Fama \& Jensen, 1983). Following the agency theory, some studies argue different theoretical clarifications about the determining factor of board composition, remarking the role of outside directors (Linck et al., 2008). Generally, different types of independent directors, such as financiers, venture capitalists, may bring different assets to the firm or constitute key stakeholders (Adams et al., 2010). An emergent body of study proposes that a resilient and vigilant board of directors may have a positive impact on the value creation in small and medium-sized businesses and start-ups such as university spin-offs, facilitating strategic change and innovation (Gabrielsson, 2007).

Taking into account the resource based view theory, small businesses such as university spin-offs are generally characterized by a lack of internal resources. In this context, it becomes critical the advisory role of the board (Daily \& Dalton, 1993), as they can provide additional knowledge that can be used by the management in generating and applying their innovative strategies (García \& García-Olalla -Ramos, 2010). In this view, the presence of outside directors on the board of small firms will reflect the missing resources needed to the CEO and the company, supporting performance and innovation efforts.

Furthermore and according to the resource dependency theory, outside directors are considered as a liaison mechanism between the firm and its environment, which can support managers in the implementation of the various objectives of the organization (Zahra \& Pearce, 1989). This aspect is critical for start-ups and small companies such as university spin-offs, which require external access to financial and human resources (Daily \& Dalton, 1993). Hence, in view of the above arguments, the following hypothesis was developed:

H2. The proportion of outside directors of university spin-offs is positively associated with firm' innovation performance.

\section{CEO-duality and innovation in university spin-offs}

The agency-based theory of corporate governance usually proposes that the positions of CEO and Chair of the board should be distinct. Indeed, merging the positions (CEO-duality), it is claimed prejudice the capacity of the board to monitor the company (Fama \& Jensen, 1983; Coles et al., 2001), since the single individual may engage friendly directors and hinder the flow of communication. In the case the CEO and chairman are distinct persons, the boards of directors are more incline to be independent, as well as more effective and efficient in monitoring managers; consequently, superior firm performance are expected. Nevertheless, stewardship theory claims that the separation between CEO and chairman can potentially avoid harmony and effectiveness in decision-making (Finkelstein \& D'aveni, 1994).

With specific regard to the SMEs context, such as the majority of university spin-offs, the position of chairman and chief executive officer is usually held by a single person. This practice has attracted much criticism based on the agency theory (Pugliese \& Wenstøp, 2007). Also in the case of small firms, the need for a separation of the two 
roles is linked to the fact of how the board is called to monitor the actions of top management and evaluate their performance (Gabrielsson et al., 2007). Indeed, in SMEs independent leadership may lead to a balance of power between the CEO and the chairman of the board, improving the firm's performance (Rashid \& Lodh, 2011).

Furthermore, also if CEO-duality may potentially stimulate the interests of the close members of firms, it may limit the benefits from hiring the best existing professional managers that can be particularly large for innovative activities in university spin-offs. Accordingly, the following hypothesis was developed:

H3. There is a negative association between the CEO-duality and innovation performance for university spin-offs.

\section{Method}

\section{Sample and Data}

With the aim to empirically investigate the hypothesis developed, sample and data employed are drawn from the national network of Netval at December 2015, which collect updated information about the full population of active spin-offs in Italy, while data cover a period from 2010 to 2014. From the initial population were excluded those companies resulting inactive, in liquidation or ceased from the certified company registration of Infocamere extracted from the database of the Italian Chambers of Commerce. This results in a final sample of 478 Italian university spin-offs, whose qualitative data were sourced from the same database of Infocamere, from corporate and home university websites and, in relation to the accounting data from the Aida BdV database, which contains historical financial, biographical and merchandise data of about 700,000 Italian active companies.

\section{Variables definition}

\section{Dependent variable}

The dependent variable applied in this study, the innovation performance of university spin-offs, was measured by a dummy variable that takes the value 1 if the university spin-off had innovative activity and 0 otherwise, as declared by companies and reported in the original database used for the study (see Section Sample and Data for details).

\section{Independent variables}

With the aim to predict the effect of board size on the innovation performance of university spin-offs (BOARD SIZE), it was used the natural logarithm of total number of members of the board of directors. The transformation in $\log$ is due to problems with non-normal distributions.

The impact of outside directors on innovation performance of university spin-offs (OUTSIDE DIRECTORS) was calculated as the ratio of external directors on the board. The purpose of this variable is to measure the board's monitoring capability, with the aim to examine its impact on the firm' innovation.
Finally, in order to measure the impact of CEO-duality on innovation performance of university spin-offs (DUALITY), it was used a dummy variable which takes value 1 if the chairman and the $\mathrm{CEO}$ are the same person and 0 otherwise.

\section{Control variables}

It is to note that firm size impacts on innovative efforts of the firm. Indeed small companies are more able to innovate compared to the bigger ones, consistently to the innovative efforts involved by the firm. Hence, we control for firm size (SIZE) by using the natural logarithm of total assets.

Furthermore, we control for firm age (AGE) by using the natural logarithm of the number of years since the firm was incorporated.

In addition, firm performance has also been remarked to affect innovation performance. The accounting performance was computed by using two profitability ratio, namely return on assets (ROA) and return on equity (ROE). Each measure was measured by dividing net income by total assets and total shareholder equity respectively.

\section{Analytical approach}

In order to test the research hypotheses developed it has been used a binary probit GLM in the estimation of parameters, which is particularly suitable in case of dichotomous dependent variables. The use of ordinary least square (OLS) regression is inappropriate for this type of dependent variables because the possible range of values is limited to two sides of the interval [0-1]. Furthermore, this statistical method is designed for a maximum-likelihood estimation of the number of rates of non-negative counts.

\section{Results}

\section{Univariate analysis}

Table 1 presents descriptive statistics for the variables in the analysis. We show minimum, maximum, mean and standard deviation values for the university spin-offs in the sample. The results indicate that the sampled university spin-offs show a medium-low degree of innovation performance, with a mean value of $14.9 \%$ of firms with innovation and a moderate dispersion in the sample (S.D. $=35.58 \%$ ).

Furthermore, the results show that, on average there are $32.12 \%$ of outside directors on the board with a moderate dispersion in the sample (S.D. = 37.63). With reference to the leadership structure, in the $31.7 \%$ of the university spin-offs of the sample, both the figures of Chairman and CEO are the same person, although this value is quite heterogeneous in the sample (S.D. = 46.55). According to board size, the mean value is $2-3$ members per board, with a medium-low dispersion in the sample (S.D. = 1.69). It seems that the boards of the university spin-offs in the sample are quite small. In relation to the control variables, the firms in mean have 8 years, a value with a medium-low homogeneity in the sample (S.D. = 3.78), remarking that spin-off is a recent phenomenon in Italy. Regarding firms size, the sample have on average $453,907.06$ of total assets, although this value is high heterogeneous in the sample (S.D. $=1,167,610.94)$. Fi- 
nally, regarding the accounting performance of university spin-offs sampled, the results reveal a mean of ROE of 3.27 and a mean of ROA of 0.17 , but the same values are quite dispersed in the sample, remarking the heterogeneity in the performance of this kind of firms and their difficulties in creating new value.
Table 2 reports the bivariate Pearson correlations among all variables used in the study. Given the lack of sufficient high correlations among the independent variables, issues of nonsense correlation are not detected. To test for multicollinearity, the VIF was calculated for each independent variable. Myers (1990) suggests that a VIF value of 10 and above is cause for concern. The results (not shown in this paper) indicate that all the independent variables had VIF values of less than 10 .

Table 1.Descriptive statistics.

\begin{tabular}{|c|c|c|c|c|c|}
\hline Variables & $\mathrm{N}$ & Min. & Max. & Mean & S.D. \\
\hline INNOVATION & 2590 & 0.000 & 1.000 & 0.149 & 0.356 \\
\hline OUTSIDE DIRECTORS & 2590 & 0.000 & 100.000 & 32.128 & 37.634 \\
\hline AGE & 2590 & 1.000 & 29.000 & 8.021 & 3.789 \\
\hline SIZE & 2139 & 2865.000 & 12072852.000 & 453907.066 & 1167610.943 \\
\hline $\mathrm{ROA}$ & 2137 & -428.760 & 88.250 & 0.177 & w30.496 \\
\hline
\end{tabular}

Source: authors

Table 2. Correlations.

\begin{tabular}{|c|c|c|c|c|c|c|c|c|c|}
\hline & & 1 & 2 & 3 & 4 & 5 & 6 & 7 & 8 \\
\hline 1 & INNOVATION & 1 & $0.077^{\star *}$ & $-0.039^{*}$ & 0.039 & $-0.395^{* *}$ & $-0.112^{* *}$ & -0.038 & -0.012 \\
\hline 2 & BOARD SIZE & $0.077^{* *}$ & 1 & $0.088^{* *}$ & $-0.441^{* *}$ & $-0.073^{* *}$ & $0.196^{* *}$ & $0.125^{* *}$ & $0.091^{* *}$ \\
\hline 3 & OUTSIDE DIRECTORS & $-0.039^{*}$ & $0.088^{* *}$ & 1 & $-0.068^{* *}$ & $0.042^{*}$ & $0.238^{* *}$ & $-0.117^{* *}$ & $-0.114^{* *}$ \\
\hline 4 & DUALITY & 0.039 & $-0.441^{* *}$ & $-0.068^{* *}$ & 1 & -0.025 & $0.056^{*}$ & -0.004 & -0.016 \\
\hline 5 & AGE & $-0.395^{* *}$ & $-0.073^{* *}$ & $0.042^{*}$ & -0.025 & 1 & $0.375^{* *}$ & $-0.050^{*}$ & $-0.048^{*}$ \\
\hline 6 & SIZE & $-0.112^{* *}$ & $0.196^{* *}$ & $0.238^{* *}$ & $0.056^{\star}$ & $0.375^{\star *}$ & 1 & $0.065^{* *}$ & $0.119^{* *}$ \\
\hline 7 & ROA & -0.038 & $0.125^{* *}$ & $-0.117^{* *}$ & -0.004 & $-0.050^{*}$ & $0.065^{* *}$ & 1 & $0.749^{* *}$ \\
\hline 8 & $\mathrm{ROE}$ & -0.012 & $0.091^{* *}$ & $-0.114^{* *}$ & -0.016 & $-0.048^{*}$ & $0.119^{* *}$ & $0.749^{* *}$ & 1 \\
\hline
\end{tabular}

${ }^{\star * *} \mathrm{p}<0.001 ;{ }^{* *} \mathrm{p}<0.01 ;{ }^{*} \mathrm{p}<0.05$; (all two-tailed tests). Source: authors

\section{Multivariate analysis}

Table 3 shows the results of the binary probit GLM in the estimation of innovation performance of university spin-offs. The regression analyses are performed in a step-wise manner. column I includes all the control variables; columns II, III, IV and V refer to the three main effects, entered one by one, while column VI represents the full model.
H1 remarks an inverted-U-shaped relationship between the size of the board and innovation performance for university spin-offs. Our results (column II) show first a positive and statistically significant estimated coefficient on BOARD SIZE (coeff. $=0.377, \mathrm{p}<0.05$ ) and, then, a negative and statistically significant estimated coefficient on its square (coeff. $=-0.330, \mathrm{p}<0.01$ ). However, our findings (column III) show a significant negative estimated coefficient on BOARD SIZE (coeff. $=-0.169, \mathrm{p}<0.01$ ). Thus, these results support $\mathrm{H} 1$. 
$\mathrm{H} 2$ states that the proportion of outside directors of university spinoffs is positively associated with firm' innovation performance. In the column IV, the estimated coefficient on OUTSIDE DIRECTOS is slightly positive and not statistically significant, so not supporting $\mathrm{H} 2$.

Finally, $\mathrm{H} 3$ states a negative association between the CEO-duality and innovation performance for university spin-offs. In the column $\mathrm{V}$, the estimated coefficient on DUALITY is negative and not statistically significant, thus not supporting $\mathrm{H} 3$.

Hence, the results of our regression evaluating the influence of board composition on innovation performance for university spin-offs seem to reveal that only board size have a critical function on the innovation activity of the firm.

Table 3. GLM binary probit regression estimation predicting the effect of board composition on innovation performance of university spin-offs.

\begin{tabular}{|c|c|c|c|c|c|c|c|c|c|c|c|c|}
\hline \multirow[t]{2}{*}{ Variables } & \multicolumn{2}{|c|}{ (I) } & \multicolumn{2}{|c|}{ (II) } & \multicolumn{2}{|c|}{ (III) } & \multicolumn{2}{|c|}{ (IV) } & \multicolumn{2}{|c|}{ (V) } & \multicolumn{2}{|c|}{ (VI) } \\
\hline & B & S. E. & B & S. E. & B & S. E. & B & S. E. & $\mathrm{B}$ & S. E. & $\mathrm{B}$ & S. E. \\
\hline \multicolumn{13}{|l|}{ Control variables } \\
\hline AGE & $1.170^{* * *}$ & $(0.0911)$ & $1.144^{* * *}$ & $(0.0914)$ & $1.137^{\star * *}$ & $(0.0910)$ & $1.171^{\star * \star}$ & $(0.0917)$ & $1.197^{\star * *}$ & $(0.0926)$ & $-0.241^{* * *}$ & $(0.0202)$ \\
\hline SIZE & -0.029 & $(0.0322)$ & -0.008 & $(0.0333)$ & -0.007 & $(0.0331)$ & -0.031 & $(0.0326)$ & -0.034 & $(0.0326)$ & 0.003 & $(0.0054)$ \\
\hline ROA & 0.000 & $(0.0026)$ & 0.000 & $(0.0027)$ & 0.000 & $(0.0027)$ & 0.000 & $(0.0026)$ & 0.000 & $(0.0026)$ & 0.000 & $(0.0005)$ \\
\hline ROE & 0.002 & $(0.0017)$ & 0.002 & $(0.0018)$ & 0.002 & $(0.0018)$ & 0.002 & $(0.0017)$ & 0.002 & $(0.0017)$ & 0.000 & $(0.0003)$ \\
\hline \multicolumn{13}{|l|}{$\begin{array}{l}\text { Hypothesized } \\
\text { effects }\end{array}$} \\
\hline BOARD SIZE & - & - & $0.377^{\star}$ & $(0.1906)$ & $-0.0169^{* *}$ & $(0.0639)$ & - & - & & & -0.030 & $(0.0420)$ \\
\hline $\begin{array}{l}\text { B O A R D } \\
\text { SIZE }^{2}\end{array}$ & - & - & $-0.330^{* *}$ & $(0.1122)$ & - & - & - & - & & & 0.047 & $(0.0255)$ \\
\hline $\begin{array}{l}\text { O U T S I D E } \\
\text { DIRECTORS }\end{array}$ & - & - & - & - & - & - & 0.000 & $(0.0011)$ & & & 0.000 & $(0.0002)$ \\
\hline DUALITY & - & - & - & - & - & - & - & - & -0.012 & $(0.0844)$ & 0.033 & $(0.0191)$ \\
\hline $\begin{array}{l}\text { Likelihood-ratio } \\
\text { chi-square }\end{array}$ & $204.121^{\star * *}$ & & $221.024^{* * *}$ & & $211.894^{\star * *}$ & & $204.172^{* * *}$ & & $207.722^{* * *}$ & & $254.203^{* * *}$ & \\
\hline DF & 4 & & 6 & & 5 & & 5 & & 5 & & 8 & \\
\hline
\end{tabular}

${ }^{* * *} \mathrm{p}<0.001 ;{ }^{* *} \mathrm{p}<0.01 ;{ }^{*} \mathrm{p}<0.05$; (all two-tailed tests). Robust standard errors in parenthesis. Source: authors

\section{Results discussion and conclusions}

The paper aimed to study the role played by the board of directors, in its some different characteristics and composition, on innovation performance of university spin-offs. In detail, and based on existing literature and theoretical arguments, mainly referring to the agency theory, the resource based view theory and the resource dependency theory, it was stated that board size has a non-linear effect on innovation performance of university spin-offs, while the presence of outside directors and the CEO-duality have, respectively, positive and negative effect on the innovation performance of the university start-ups.

In order to test the developed hypotheses, a panel sample of 478 Italian university spin-offs was investigated during an exploration period of four years, from 2010 to 2014. The results show that the board size seems to have, first, a positive impact on innovation of university start-up and, then, a negative effect with the increase of directors in their composition. These findings is in line with those of De Andrés et al. (2005), remarking that not too large boards of directors are more efficient and work better, influencing in a positive way the innovation activity of the firm too. On the other hand, the findings contrast with other studies (García-Olalla \& García-Ramos, 2010), which highlighted that increasing the board size improves firm performance. However, the results of the current study remark, according to Jensen (1993), that the benefits of adding more directors on the board appear to be outweighed by the issues link to inefficient communication and harmonization of great boards.
Regarding the impact of the outside directors, the results seems to invalidate its positive and significant effect on innovation performance of the university spin-offs. This evidence appear to deny the postulation that outside directors have a key and superior monitoring, social and advising role compare to the internal directors. However, Hermalin \& Weisbach (1991) propose that both inside and outside directors may be unsuccessful in accomplishing their function of representing shareholders' interests correctly, i.e., it cannot be argued that outsiders accomplish their functions better than insiders. Additionally, usually outside directors lack key knowledge of the firm compared to the insides, as well as they are unfamiliar with the activity and resources of the firms, including innovative ones. This lack of knowledge of outsiders seems to be potentially more evident in the university spin-offs.

Also the CEO-duality seems to have no influence on the innovation performance of the university spin-offs. The irrelevance of the duality effect, although in contrast with the findings reported by Coles et al. (2001), it is in line with the empirical evidences of Elsayed (2007) with reference to the firm performance. In line of the observations obtained from the study, it could be argued that in the university spinoffs context the separation of the figures of CEO and chairman is does not have implication in term of innovative activity of the firm. The reasons may be associated to the fact that for university start-ups the stewardship theory have major role compared to the agency theory; hence, the separation between CEO and chairman may be beneficial in term of coordination and effectiveness in decision-making. 
The study has some interesting practical and policy implications. The findings of the current study may represent potential indicators of the most proper configuration for board of directors in university spin-offs with the purpose to improve their innovation performance. First, it is important for university spin-offs have a good and better represented (with reference to the stakeholder's interest) board of directors, improving their monitoring effectiveness and commitment in innovative activities; although it is important that the board not becoming too large in order to avoid problems of coordination and effectiveness in decision-making process related to the innovation strategy. Second, since outside directors seem to no promote innovation, or not have influence on the correlated activities, maybe university spin-offs need to select and attract external directors that will be more suitable for the firm. Outsider selection is important because must give professionalism to the board. Indeed, outside directors are useful to the firms if they add further and complementary expertise and capability, which should to be able to improve together the innovation efforts of the university stat-ups.

Nevertheless, the study is not free of limitations. First, although the paper use panel data, the relative short period of investigation limit the robustness of the causal relations among the dimensions investigated. Therefore, future studies may will be benefit from collect additional time's series data in a medium-long period, in order to improve the effectiveness and clarification of the assumptions associated with the causality of the relations studied. Second, although the comparability of Italian university spin-offs data with those of the overall European context, additional data on European spin-offs and comparison among countries are needed in order to increase the probability of generalizing the emerging empirical evidence and build a more robust and specific theoretical background on the matter.

\section{References}

Adams, R. B., Hermalin, B. E., \& Weisbach, M. S. (2010). The role of boards of directors in corporate governance: A conceptual framework and survey. Journal of Economic Literature, 48(1), 58-107.

Belloc, F. (2012). Corporate governance and innovation: A survey. Journal of Economic Surveys, 26(5), 835-864.

Bjørnåli, E. S., \& Gulbrandsen, M. (2010). Exploring board formation and evolution of board composition in academic spin-offs. The Journal of Technology Transfer, 35(1), 92-112.

Cheng, S. (2008). Board size and the variability of corporate performance. Journal of Financial Economics, 87(1), 157-176.

Coles, J. W., McWilliams, V. B., \& Sen, N. (2001). An examination of the relationship of governance mechanisms to performance. Journal of management, 27(1), 23-50.

Colombo, M. G., Croce, A., \& Murtinu, S. (2014). Ownership structure, horizontal agency costs and the performance of high-tech entrepreneurial firms. Small Business Economics, 42(2), 265-282.
Daily, C. M., \& Dalton, D. R. (1993). Board of directors leadership and structure: Control and performance implications. Entrepreneurship: Theory and Practice, 17(3), 65-82.

De Andres, P., Azofra, V., \& Lopez, F. (2005). Corporate boards in OECD countries: Size, composition, functioning and effectiveness. Corporate Governance: An International Review, 13(2), 197-210.

Djokovic, D., \& Souitaris, V. (2008). Spinouts from academic institutions: a literature review with suggestions for further research. The Journal of Technology Transfer, 33(3), 225-247.

Eisenberg, T., Sundgren, S., \& Wells, M. T. (1998). Larger board size and decreasing firm value in small firms. Journal of financial economics, 48(1), 35-54.

Elsayed, K. (2007). Does CEO duality really affect corporate performance?. Corporate Governance: An International Review, 15(6), 1203-1214.

Fama, E. F., \& Jensen, M. C. (1983). Separation of ownership and control. The Journal of Law \& Economics, 26(2), 301-325.

Finkelstein, S., \& D’aveni, R. A. (1994). CEO duality as a double-edged sword: How boards of directors balance entrenchment avoidance and unity of command. Academy of Management journal, 37(5), 1079-1108.

Gabrielsson, J. (2007). Correlates of board empowerment in small companies. Entrepreneurship Theory and Practice, 31(5), 687-711.

Gabrielsson, J., Huse, M., \& Minichilli, A. (2007). Understanding the leadership role of the board chairperson through a team production approach. International Journal of Leadership Studies, 3(1), 21-39.

García-Olalla, M., \& García-Ramos, R. (2010). Family ownership, structure and board of directors effectiveness: Empirical evidence from European firms. In 9th Annual IFERA Conference, Lancaster, United Kingdom.

Gaver, J. J., \& Gaver, K. M. (1995). Compensation policy and the investment opportunity set. Financial management, 24(1), 19-32.

Guerrero, M., Urbano, D., \& Fayolle, A. (2016). Entrepreneurial activity and regional competitiveness: evidence from European entrepreneurial universities. The Journal of Technology Transfer, 41(1), 105-131.

Hayton, J. C. (2005). Competing in the new economy: the effect of intellectual capital on corporate entrepreneurship in high-technology new ventures. R\&D Management, 35(2), 137-155.

Hermalin, B. E., \& Weisbach, M. S. (1991). The effects of board composition and direct incentives on firm performance. Financial management, 20(4), 101-112. 
Jackling, B., \& Johl, S. (2009). Board structure and firm performance: Evidence from India’s top companies. Corporate Governance: An International Review, 17(4), 492-509.

Jensen, M. C. (1993). The modern industrial revolution, exit, and the failure of internal control systems. The Journal of Finance, 48(3), 831-880.

Linck, J. S., Netter, J. M., \& Yang, T. (2008). The determinants of board structure. Journal of Financial Economics, 87(2), 308-328.

Niosi, J. (2006). Success factors in Canadian academic spin-offs. The Journal of Technology Transfer, 31(4), 451-457.

Palumbo, R. (2010). Dall'Università al mercato. Governance e performance degli spinoff universitari in Italia. Milano: Franco Angeli.

Pugliese, A., \& Wenstøp, P. Z. (2007). Board members' contribution to strategic decision-making in small firms. Journal of Management \& Governance, 11(4), 383-404.
Rashid, M. A., \& Lodh, S. C. (2011). Corporate governance and performance of small and medium sized enterprise (SME): evidence from Bangladesh. Faculty of Commerce - Papers, 1-44, (2011).

Sternberg, R. (2014). Success factors of university-spin-offs: Regional government support programs versus regional environment. Technovation, 34(3), 137-148.

Visintin, F., \& Pittino, D. (2014). Founding team composition and early performance of university-Based spin-off companies. Technovation, 34(1), 31-43.

Zahra, S. A., \& Pearce, J. A. (1989). Boards of directors and corporate financial performance: A review and integrative model. Journal of management, 15(2), 291-334. 